\title{
Fire and cattle grazing on wintering sparrows in Arizona grasslands
}

\author{
CALEB E. GORDON
}

Author's address (at time of research-present): Department of Ecology and Evolutionary Biology, BSW rm. 310, University of Arizona, Tucson, Ariz. 85721 .

Abstract

This paper reports on the results of a 3-year field study of the effects of spring/summer burning and cattle grazing on wintering sparrows in the grasslands of southeastern Arizona. The effects of fire were studied with 1 year of pre-burn data and 1 year of post-burn data from 1 fire, plus limited sampling from a second fire at Buenos Aires National Wildlife Refuge in Pima County, Ariz. The effects of grazing were studied by comparing study plots at a site that has not been grazed by cattle since 1968 with a nearby grazed pasture in Santa Cruz County, Ariz. Sparrow abundance was measured as the number of captures from flushnetting sessions conducted by groups of 13-30 volunteers. Vesper (Pocecetes gramineus (Gmelin)) and Savannah (Passerculus sand wichensis (Gmelin)) Sparrows responded positively to fire, while Cassin's Sparrows (Aimophila cassinhi (Woodhouse)) responded negatively. The ecologically and geographically restricted Baird's (Ammodramus bairdil (Audubon)) and Grasshopper (A. savan narum (Gmelin)) Sparrows utilized burned areas during the first post-burn winter and did not significantly respond to fire. Both Ammodramus sparrows also utilized the grazed pasture; they were more abundant there than in the ungrazed study area in 1 year. While field observations and a prior study suggest that heavy grazing can have a strong detrimental effect on Ammodramus sparrows, the results of this study suggest that moderate cattle grazing may be compatible with the conservation of these species.

Key Words: birds, conservation, bird-banding

The grasslands of the borderlands region of the southwestern United States are a crucible for the interaction between, and the

Research was funded in part by a predoctoral fellowship from NSF, USFWS agreement \#1448-00002-95-0850, The American Ornithologists' Union, The Research Ranch Foundation, the James R. Silliman Memorial Foundation, the Research Training Grant in the Analysis of Biological Diversification at the University of Arizona, and the University of Arizona Department of Ecology and Evolutionary Biology. The author wishes to thank Robert Robichaux for comments on an earlier version of the manuscript, Grant Drennen of the USBLM Tucson field office for the livestock data, Janet Ruth of the USGS Ivlidcontinent Ecological Science Center for comments on an earlier version of the manuscript, and for contributing assistants for field work, and the $600+$ people who participated in sparrow flushing, especially Josh Anderson, Ellie Beck, Emily Bennett, Cheryl Carnes, Ed Chicardi, Canny Clark, Nigel Crook, Erv Davis, Natalie Doerr, Jon Dorio, Anne Eyechaner, Kate Fournier, Bill Flack, Tom Gaskill, Chris Hanus, Ron Hummel, Matt Kaplan, Andre Lehovich, Wade Leitner, Tom Locascio, Jenine McCabe, Lou McMurray, Aaron, Danetta, Mark and Jordan Mecikalski, Susan Meredith, Charles Pope, Earle Robinson, Bob Shank, Karen Short, Jay Taylor, Eliott and Rosemary Valentine, Caroline Van Hemert, and Bob Whitcomb.

Manuscript accepted 22 Oct. 1999.

\section{Resumen}

Este articulo reporta los resultados de un estudio de campo de 3 años en el que se determinaron los efectos de la quema en primavera/verano y el apacentamiento de ganado sobre los gorriones invernantes en los pastizales del sudeste de Arizona. Los efectos del fuego se estudiaron con datos de 1 año antes de la quema y con datos de 1 año después de una quema, mas un muestreo limitado de una segunda en el Refugio Nacional de Fauna Silvestre Buenos Aires situado en el condado de Pima, Ariz. Los efectos del apacentamiento se estudiaron mediante la comparación de parcelas localizadas en un sitio que no había recibido apacentamiento desde 1988 y en parcelas situadas en potrero cercano que estaba siendo apacentado, estos sitios se ubican en Santa Cruz, Ariz. La abundancia de gorriones se midió como el número de capturas en sesiones de redeo conducidas por grupos de 13 a 30 voluntarios. Los gorriones "Vésper" (Pooecetes gramineus (Gmelin)) y "Savannah" (Passerculus sandwichensis (Gmelin)) respondieron positivamente al fuego, mientras que los gorriones "Cassin" (Aimophila cassinii (Woodhouse)) respondieron negativamente. Los gorriones "Baird" (Ammodramus bairdii (Audubon)) y "Grasshopper" (A. savannarum (Gmelin)), que están ecológicamente y geográficamente restringidos, utilizaron las áreas quemadas durante el primer invierno después de la quema y no respondieron significativamente al fuego. Ambas especies de gorrión del genero Ammodramus también utilizaron los potreros apacentados, en un año, ellos fueron más abundantes allí que en los potreros sin apacentamiento. Mientras las observaciones de campo y un estudio previo sugieren que el apacentamiento severo puede tener un fuerte efecto detrimental en los gorriones Ammodramus los resultados de este estudio sugieren que el apacentamiento moderado puede ser compatible con la conservación de estas especies.

coexistence of, ecologically restricted biodiversity and economically important cattle grazing. These are the most biologically diverse grasslands in the country and they contain many specialized and endemic species (Whitford et al. 1995, Parmenter and Van Devender 1995). During winter, these grasslands are home to endemic subspecies of Grasshopper Sparrow (Ammodramus savannarum ammolegus (Gmelin)) and Eastern Meadowlark (Sturnella magna lilianae (Linnaeus)), and geographicallyrestricted Baird's Sparrow (Ammodramus bairdii (Audubon)) and Sprague's Pipit (Anthus spragueii (Audubon)), all of which are restricted to grassland habitats within their limited geographic ranges (Phillips et al. 1964). Among the species in this study, Grasshopper, Baird's, and Cassin's Sparrows (Aimophila cassin nii (woodhouse) have been identified as species of management 
concern both nationally (USFWS 1995) and in Arizona (Latta et al. 1999).

The grasslands of the southwestern borderlands are also the most productive lands for cattle grazing in the region. The plains and semidesert grasslands in this region have been described as, "...the lifeblood of southern Arizona's cattle industry." (Bahre 1995). It is therefore essential that we understand the interaction between cattle grazing management practices and wildlife to develop management strategies that meet both economic and conservation goals.

The current study examines the responses of wintering sparrows to the 2 most significant range management practices in the grasslands of southern Arizona: fire and cattle grazing. Fire is currently used in southern Arizona grasslands both to manage for native grassland biodiversity and to enhance herbaceous forage production for cattle. While historical evidence of grassland fires is scarce, it is widely accepted that fires ignited during spring and summer by lightning and/or native Americans were a regular historical occurrence (Bahre 1991, McPherson 1995). In this region, fire kills most shrubs and reduces mesquite (Prosopis spp.) recruitment for up to 20 years (Humphrey 1949), while grasses and herbaceous dicots generally return to pre-burn densities in 1 to 3 years (Cable 1967, Bock et al 1976, Wright and Bailey 1980, Cox et al. 1990, Bock and Bock 1990, 1992).

Cattle are currently grazed on virtually all grassland habitat in the borderlands region. The historical and ecological roles of cattle grazing on southwestern rangelands are complex and controversial (see Bahre 1991, reviews by Fleischner 1994, Brown and McDonald 1995). While large ungulate grazers may be viewed, on the one hand, as a natural and coevolved component of some grassland ecosystems (McNaughton 1993), the arid grasslands of the borderlands region are among the least productive grasslands and are dominated by grasses with life history attributes that make them relatively intolerant of cattle grazing (Mack and Thompson 1982, Fleischner 1994). Nonetheless, cattle grazing is much less disruptive to the native grassland community than are several alternative land uses such as row crop agriculture or residential development (Brown and McDonald 1995). Despite the ecological and economic prominence of cattle grazing in southern Arizona, we know very little about the effects of cattle grazing on plant and animal communities of this region (Bahre 1995, but see
Fleischner 1994). Some attribute the widespread conversion of the region's grasslands to shrublands largely to the effects of cattle grazing (Bahre 1991), while others believe that this transition came about largely because of a drying climate (Hastings and Turner 1965, Johnson and Mayeux 1992).

Although grassland bird communities are typically low in diversity, they are a top national conservation priority because of the high proportion of threatened and declining species they contain (Knopf 1994, USFWS 1995). All 6 sparrow species in this study have been identified as threatened or of management concern by various state and/or federal wildlife regulatory agencies. The Baird's Sparrow is of special concern because of its extremely restricted geographic range, its narrow habitat restriction within this range, its recent range contraction and population declines, and the virtual lack of any information on the winter biology of this species (USFWS 1995, Jones and Green 1998, Latta et al. 1999). The congeneric Grasshopper Sparrow is also a species of management concern because of its similar restriction to grassland habitat, recent population declines, and a subspecies (A. s. ammolegus) that is endemic to the borderlands region (USFWS 1995, Latta et al. 1999). The Cassin's Sparrow is less of a grassland specialist than the previous 2 species but is also a species of management concern in the Southwest based on its small geographic range and recent population declines in some areas (USFWS 1995, Latta et al. 1999, Ruth 1999). Savannah Sparrow (Passerculus sandwichensis (Gmelin)), Vesper Sparrow (Pooecetes gramineus (Gmelin)), and Brewer's Sparrows (Spizella breweri Cassin) are all species of management concern in other regions, but are abundant, widespread, and not currently considered to be of significant management concern in the southwestern United States (USFWS 1995).

Emberizine sparrows comprise a predominant component of the wintering grassland bird community of southern Arizona. Six species of sparrows account for over $99 \%$ of all birds captured during this study. Vesper, Savannah, Baird's, and Brewer's sparrows only occur in this region as migrants and winter residents, while Cassin's and Grasshopper sparrows can be found in southern Arizona grasslands year-round (Rising 1996).

Previous information on the effects of fire and grazing on the wintering grassland sparrow community of southern Arizona is limited to 3 published data sets. After a fire in April 1974, Bock et al. (1976) reported that in the subsequent winter, Grasshopper Sparrows were more abundant on unburned areas while Vesper and Savannah Sparrows were more abundant on the burned area. After a fire at the same study site in July 1987, Bock and Bock (1992) reported that Grasshopper and Cassin's Sparrows showed no preference for burned versus unburned areas while Vesper and Savannah Sparrows again were more abundant on the burned area during the subsequent winter. Furthermore, they reported that all significant differences in abundance disappeared by the second or third post-burn winter. In the only published study of the effects of cattle grazing on wintering grassland birds in southern Arizona, Bock et al. (1984) found that Cassin's and Grasshopper Sparrows were more abundant in an ungrazed area while Brewer's Sparrows were more abundant in a grazed pasture.

\section{Materials and Methods}

\section{Sparrow Flushing}

Standard sparrow flushing plots consisted of a 100-m net line, with a 3.5-ha flushing zone fanning out on each side (Fig. 1). For each day of flush-netting, crews of 13-30 people (avg 22) assembled at 0830 hour at the field site to perform the following field protocol: Eight, 2 x 12 m, 36-mm mesh mist nets were set up along the net line at the first plot. When the nets were ready, the field crew fanned out along the $300 \mathrm{~m}$ back edge of one flushing zone. With people spread out evenly along the periphery of the flushing zone, a signal was given and the group walked through the flushing zone toward the net line. This caused the sparrows to flush toward the nets. Many were caught in the nets because of the low-flying behavior of sparrows in this habitat. The crew would then repeat this procedure for the second flushing zone on the other side of the net line.

After flushing both sides of a study plot, all netted birds were banded with individually-numbered, USFWS aluminum leg bands. If they already possessed a band (recaptures), the band number was recorded.

We then disassembled the nets at the first plot and repeated the entire procedure at the next plot. In this way, we flush-netted all plots at a study site in random sequence on each day of flush-netting. 


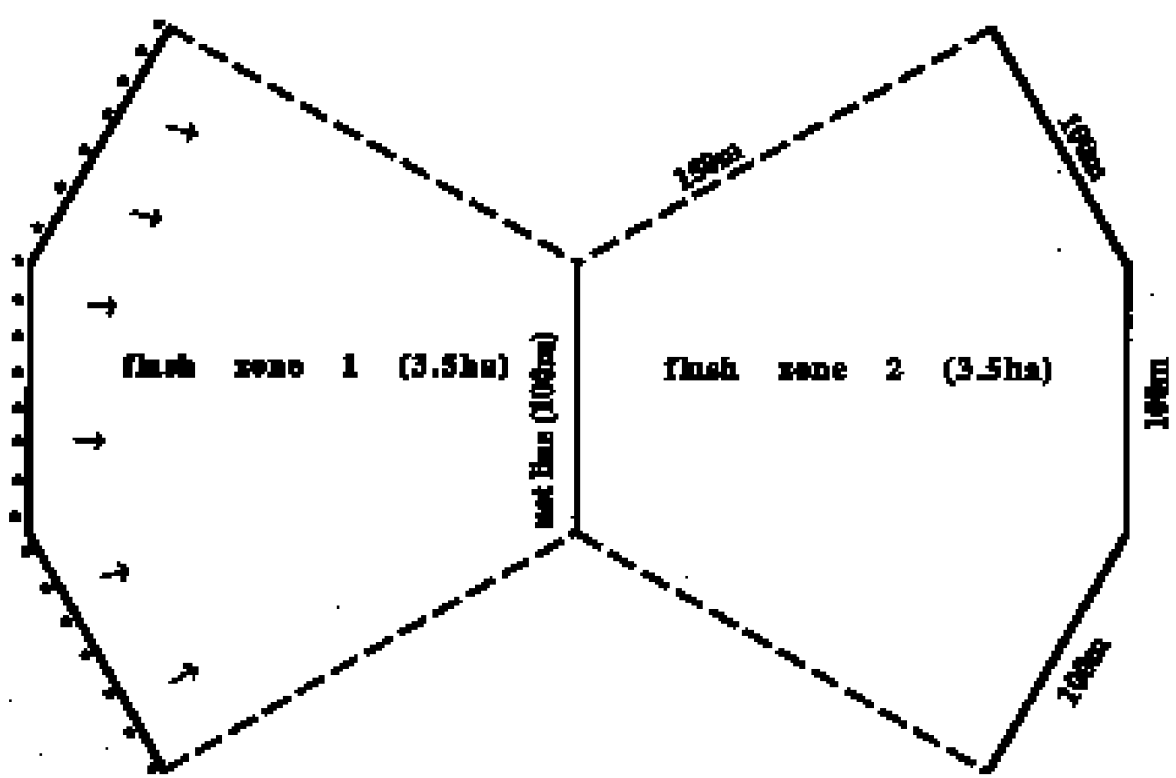

Fig. 1. Schematic representation of a standard sparrow flushing plot. Asterisks represent people $(22=\mathbf{a v g})$ ready to flush one of the zones by walking together in the direction ofthe arrows.

\section{Fire Effects}

The prescribed burning program at the Buenos Aires National Wildlife Refuge in Pima County, Ariz. provided the vehicle for examining the effects of fire on wintering grassland sparrow communities. The main portion of this 46,640-ha refuge is located in the broad, flat Altar valley, (Lat. $32^{\circ} 30^{\prime} \mathrm{N}$, Long. $111^{\circ} 30^{\prime} \mathrm{W}$ ) between 940 and 1,372 $\mathrm{m}$ elevation, and is dominated by mesquite savannah and semidesert grassland vegetation. Domestic livestock were removed when it was established as a National Wildlife Refuge in 1985. Although controlled burns have been conducted on the Buenos Aires National Wildlife Refuge since 1988, an aggressive program of prescribed burning was implemented in 1996 with the goal of managing for the native plant and animal communities of semidesert grassland.

Six sparrow flushing plots were established in upland grassland that had not been burned for at least 3 years. Because of the high density of shrubs, especially concentrated in washes on the Refuge, plot locations were determined by visual selection of relatively flat, shrub-free areas. Each of these plots was flushed for sparrows (see below) once per week for 9 weeks between early January. and early March 1997. In April 1997, 3 of the study plots were burned in a single fire (plots 1 , 2, and 3). The 1997 sparrow flushing sampling scheme was then repeated on the same 6 plots between January. and March 1998. In April 1998, another fire burned plot 5 and half of plot 6 . Sparrow flushing was then conducted on all 6 plots 3 times between January and March 1999, although data for plot 6 (half-burned) are not reported.

\section{Grazing Effects}

The study of the effects of cattle grazing on wintering grassland sparrow communities was conducted at 2 sites in the Sonoita Valley in Santa Cruz County, Ariz. The Audubon, or Appleton-Whittell Research Ranch near Elgin, Ariz., (Lat. $31^{\circ} 38^{\prime} \mathrm{N}$, Long. $110^{\circ} 33^{\prime} \mathrm{W}$ ) has not been grazed by domestic livestock since 1968. The Ranch covers 3,160 hectares of plains grassland and oak savannah vegetation between 1,400 and $1,500 \mathrm{~m}$ elevation. Six flushing plots were established in relatively treeless upland mesa grassland in the northwestern quarter of the Ranch. These plots were flushed once per week for 7 weeks between early January and early March 1997. The same 6 plots were again flushed once per week for 7 weeks between January and March 1998. Between January and March 1999, the same 6 plots were flushed 3 times. To standardize the 1997 and 1998 Research Ranch data with the other data sets, data from only 3 of the 7 sampling days were used, corresponding to the dates closest in time to the 3 sampling days at the grazed study site.

Grazed study plots were located on the Davis Pasture at the southern end of the USBLM's Empire Cienega Resource Conservation Area. This 1501-ha pasture is located between Elgin and Sonoita, Arizona, (Lat. $31^{\circ} 41^{\prime} \mathrm{N}$, Long. 110 $39^{\prime} \mathrm{W}$ ) roughly $10 \mathrm{~km}$ from The Research Ranch. Sparrow flushing was conducted during 3 dates per year from 1997 to 1999 between early January and early March. During 1997 and 1998, flushing was conducted on 3 to 9 plots, some of which were halfsized, and new plots were used on each flushing day. In the subsequent analysis, numbers of captures from half-sized plots were doubled to make them comparable to standard plots. In 1999, 6 standard flushing plots were used for all 3 flushing days. In the calendar years of 1996, 1997, and 1998 that immediately preceded the 3 winter seasons of sparrow flushing, this pasture received 1387, 868, and 645 AUMs of grazing pressure, respectively, concentrated during summer. No precipitation data are available but summer rainfall is reported to have been poor during 1996, 1997 , and 1998 in this pasture (Grant Drennen, pers. comm.). The desired stocking rate for this pasture is 1091 AUMs given the distribution and estimated production of USDA-NRCS range sites in the pasture, the desired utilization levels for the pasture, and excellent range condition (USBLM 1995, 1997, USDA-NRCS 1982, 1988). The USBLM rated this pasture in excellent condition in October 1995 and 1997 (USBLM 1995, 1997).

\section{Statistical Analyses}

Two-tailed t-tests for samples with heteroscedastic variance were used for statistical comparisons of sparrow densities across treatments and years for both fire and grazing studies. In both cases, the sampling units were the number of sparrow captures in individual plots on single days. While repeated sampling of plots violates the assumption of independence of samples, this violation is not serious because samples were conducted at intervals of at least a week. This sampling interval provided adequate time for birds to redistribute themselves. In essence, statistical significance was achieved only if spatial differences in density were consistent in time. Temporal constancy of spatial differences in sparrow abundance suggests that these differences resulted from biologically-real differences among study plots or years rather than random fluctuations.

\section{Results}

\section{Effects of Fire}

Twenty-one days of flushing over 3 years resulted in 1,617 captures of 8 species of sparrows at Buenos Aires National Wildlife Refuge (Table 1). 
Table 1. Mean $( \pm$ SE) captures per plot per day for 8 species of sparrow on fire study plots at Buenos Aires National Wildlife Refuge.

\begin{tabular}{|c|c|c|c|c|c|}
\hline \multirow{2}{*}{ Species } & \multicolumn{2}{|c|}{1997} & \multicolumn{2}{|c|}{1998} & \multirow{2}{*}{$\begin{array}{c}1999 \\
\text { Plots } 1,2,3(2 \\
\text { years post-burn) }\end{array}$} \\
\hline & $\begin{array}{c}\text { Plots } 1,2,3 \\
\text { pre-burn) }\end{array}$ & $\begin{array}{l}\text { Plots 4,5,6 } \\
\text { (unburned) }\end{array}$ & $\begin{array}{c}\text { Plots } 1,2,3 \text { (1 } \\
\text { year post-burn) }\end{array}$ & $\begin{array}{l}\text { Plots 4,5,6 } \\
\text { (unburned) }\end{array}$ & \\
\hline Grasshopper Sparrow & $11 \pm 1.1^{1}$ & $5.6 \pm 0.74$ & $7.4 \pm 1.2^{1,2}$ & $2.8 \pm 0.33^{2}$ & $8.1 \pm 1.5$ \\
\hline Baird's Sparrow & $0.41 \pm 0.18^{1}$ & 0 & $0.74 \pm 0.19^{1}$ & $0.11 \pm 0.062$ & $0.56 \pm 0.24$ \\
\hline Savannah Sparrow & $1.1 \pm 0.45$ & $2.9 \pm 0.68^{1}$ & $2.3 \pm 0.634^{3}$ & $2.3 \pm 0.42$ & $0.56 \pm 0.29^{2}$ \\
\hline Vesper Sparrow & $3.2 \pm 0.65$ & $4.8 \pm 1.2$ & $2.6 \pm 0.57^{13}$ & $0.74 \pm 0.31^{2}$ & $0.11 \pm 0.11^{2}$ \\
\hline Cassin's Sparrow & $0.26 \pm 0.10$ & $0.22 \pm 0.11$ & $0.93 \pm 0.23^{2}$ & $1.7 \pm 0.19^{1,2,3}$ & $2.0 \pm 0.47$ \\
\hline Brewer's Sparrow & $1.2 \pm 0.46$ & $1.6 \pm 0.54$ & $0.19 \pm 0.093^{2}$ & $0.11 \pm 0.062^{2}$ & $0.11 \pm 0.11$ \\
\hline White-crowned Sparrow & $0.074 \pm 0.074$ & $0.30 \pm 0.12$ & 0 & 0 & 0 \\
\hline Lincoln's Sparrow & $0.11 \pm 0.062$ & $0.074 \pm 0.051$ & 0 & $0.11 \pm 0.062$ & 0 \\
\hline
\end{tabular}

1 significantly higher than the other set of plots in the same year $\mathrm{p}<.05$ (see text)

2 significantly different from the same set of plots in the previous year $\mathrm{p}<.05$ (see text)

${ }^{3}$ response attributable to fire effect (see text)

Because of various non-fire-related sources of variation in sparrow abundance (see discussion), only 3 of the abundance responses shown in Table 1 can be attributed to the effects of fire. These are positive responses to fire by Savannah and Vesper Sparrows and a negative response by Cassin's Sparrow.

\section{Effects of Grazing}

Twenty-six days of flushing over 3 years resulted in 1,232 captures of 4 species of sparrows at The Research Ranch and the Davis Pasture (Table 2). Baird's Sparrows were more abundant on the grazed area than the ungrazed area in 1997 but did not differ significantly among study sites in subsequent years. Grasshopper Sparrows were more abundant on the grazed area in 1997, but were more abundant on the ungrazed area in 1998 and 1999.

\section{Discussion}

\section{Effects of Fire}

Interpreting the effects of fire on the wintering sparrow community is somewhat complex because of several additional sources of variation in sparrow density. First, there were pre-burn differences between some of the study plots. Although study plots were selected to be as similar as possible based on visual inspection of the structure and composition of the vegetation, no 2 study plots in ecological field studies can ever be perfect, identical replicates. Plots 1, 2, and 3 had significantly more Grasshopper and Baird's Sparrows than did plots 4,5 , and 6 both before and after the 1997 fire. This difference in sparrow density may have resulted from habitat differences among plots that were not measured in this study. Second, there were significant between-year differences in the density of certain sparrows that occurred regardless of fire treatment. Brewer's and

Table 2. Mean ( \pm SE) captures per plot per day for four species of sparrow on grazed (Davis Pasture) and ungrazed (The Research Ranch) study plots in the Sonoita Valley, Arizona.

\begin{tabular}{lccc}
\hline \hline Species & Year & $\begin{array}{c}\text { Davis Pasture } \\
\text { (grazed) }\end{array}$ & $\begin{array}{c}\text { The Research Ranch } \\
\text { (ungrazed) }\end{array}$ \\
\hline Grasshopper Sparrow & 1997 & $4.7 \pm 1.1^{1}$ & $0.44 \pm 0.17$ \\
& 1998 & $4.8 \pm 1.5$ & $15 \pm 2.2^{1}$ \\
Baird's Sparrow & 1999 & $1.3 \pm 0.68$ & $3.2 \pm 0.67^{1}$ \\
& 1997 & $1.3 \pm 0.39^{1}$ & $0.50 \pm 0.19$ \\
Savannah Sparrow & 1998 & $1.9 \pm 0.78$ & $1.3 \pm 0.33$ \\
& 1999 & $0.39 \pm 0.12$ & $0.83 \pm 0.32$ \\
Vesper Sparrow & 1997 & $0.32 \pm 0.20$ & $0.17 \pm 0.090$ \\
& 1998 & 0 & $2.8 \pm 1.6$ \\
& 1999 & 0 & $0.11 \pm 0.076$ \\
& 1997 & 0 & 0 \\
\hline
\end{tabular}

${ }^{1}$ significantly higher than at other study site in the same year, $\mathrm{p}<.05$ (see text)
Grasshopper Sparrows declined, while Cassin's Sparrows increased, in 1998 relative to 1997 on both burned and unburned plots. These differences may have resulted from differences in breeding success or wintering habitat conditions other than fire.

Three species exhibited significant abundance differences that can more likely be attributed to the effects of fire. Savannah Sparrows were significantly more abundant on plots 4,5 , and 6 than on plots 1, 2, and 3 in 1997 before the fire. In the winter subsequent to the fire, this difference was erased, suggesting that Savannah Sparrows responded positively to the burn. Vesper and Cassin's Sparrow abundance did not differ among plots in pre-fire 1997, but after the 1997 fire, Vesper Sparrows were more abundant on the burned plots, and Cassin's Sparrows were more abundant on the unburned plots, suggesting that Vesper Sparrows responded positively, and Cassin's Sparrows negatively to fire during the first post-burn year. The significant declines of Vesper and Savannah sparrows on plots 1, 2 , and 3 in 1999 relative to 1998 may indicate that the positive response of these species to fire only lasted 1 year. However, because the occurrence of the second fire prevents a comparison with unburned control plots, a general decrease in these sparrows from 1998 to 1999 cannot be ruled out.

As with the 2 prior studies of the effects of fire on wintering grassland sparrows, this study only reports statistically-significant effects for a single fire. Because fire is not replicated as a treatment factor, the scope of inference is limited to this particular fire at the Buenos Aires National Wildlife Refuge. Nonetheless, some general conclusions can be drawn about the effects of fire on wintering grassland sparrows in southeast Arizona by comparing the results of this study to results from the 
2 fires previously reported in the literature. Bock et al. (1976) and Bock and Bock (1992) also found that wintering Savannah and Vesper Sparrows were more abundant in burned areas after both of the fires they studied. The effects of fire on Grasshopper and Cassin's Sparrows are somewhat less consistent. In the Bock's studies, Grasshopper Sparrows were more abundant on the unburned area following the first fire (Bock et al. 1976) but showed no preference following the second fire (Bock and Bock 1992). Data for Cassin's Sparrows are only reported by Bock and Bock (1992) for their second fire, after which Cassin's Sparrows showed no preference for the burned or unburned area. No prior data are available for the effects of fire on Baird's Sparrow.

The limited replication of fire as a treatment factor adds weight to the effects of the 1998 fire. This fire only burned 1 plot completely and sparrow sampling was less intense in 1999. Therefore, sample sizes are lower and the results are not statistically significant. Nonetheless, sparrow abundances measured by 3 censuses each in plot 5 (burned in spring 1998) and plot 4 (unburned) are consistent with the 4 main patterns that emerged from the 1997 fire. Plot 5 had more Vesper (7 vs. 2) and Savannah (3 vs. 2) Sparrow captures than did plot 4, and fewer Cassin's Sparrow captures (1 vs. 4). It can also be said that the Ammodramus sparrows utilized the burned area in the first post-burn year (18 Grasshopper Sparrow captures and 1 Baird's Sparrow capture on plot 5).

\section{Effects of Grazing}

In the grazing study, the scope of inference is again limited to the study sites because the treatments were not replicated. It is notable, however, that the data demonstrate at least 1 case in which cattle grazing and Ammodramus sparrows coexisted. This pattern is worth highlighting because these species are the most ecologically (and geographically in the case of Baird's Sparrow) restricted sparrows in this community, and are both species of management concern. The coexistence of cattle grazing and Ammodramus sparrows is likely a complex balance that must be studied in more detail. Although some cattle grazing may be compatible with Ammodramus sparrows, overgrazing may reduce the abundance of these sparrows drastically. Observations in 1997 and 1998 in the Hilton Pasture, another summer pasture adjacent to the Davis Pasture on the same ranch, suggest heavier utilization of forage plants by cattle, and an almost complete lack of Ammodramus sparrows in those years (C. Gordon pers. obs.). Bock et al. (1984) also reported a case in which wintering Grasshopper and Cassin's Sparrows were more abundant on an ungrazed pasture than a grazed pasture.

\section{Management implications}

Keeping in mind the limitations on the inferences that can be made from this and previous studies, a few generalizations about the effects of fire and cattle grazing on wintering sparrows in the grasslands of Arizona are now possible. Spring burning is generally beneficial to wintering grassland sparrows. Three fires have now been examined for the short term responses of wintering sparrows to spring burning. In all 3 of these cases, 2 widespread and abundant species, Vesper and Savannah sparrows, responded positively to fire. The effects of fire on the 3 species of management concern, the Baird's, Grasshopper, and Cassin's Sparrows, are either not significant or ambiguous. Although significant decreases in response to fire have been found in single cases for Cassin's and Grasshopper Sparrows, non-significant responses to fire have also been found for both of these species. Furthermore, because fire is important for maintaining the structural characteristics of grassland habitat, the long term effects of fire are likely to be positive on these grassland dwelling sparrow species.

The effects of cattle grazing on wintering grassland sparrows are less clear. Limited data suggest that severe grazing appears to have a negative effect on the abundances of the 3 sparrow species of management concern. Nonetheless, the current study describes 1 case in which a summer-grazed pasture on an active cattle ranch had significantly higher winter abundances of both Grasshopper and Baird's Sparrows than did a nearby area that had not had livestock for 30 years. Further study is needed to assess the impacts of cattle grazing on wintering grassland bird communities. Long term as well as short term responses should be measured at multiple sites in multiple years. The current study suggests that it should be possible to find a management solution that includes both economicallyfeasible cattle ranching and suitable winter habitat for Grasshopper and Baird's Sparrows.

\section{Literature Cited}

Bahre, C.J. 1991. A legacy of change: historic human impact on the vegetation of the Arizona borderlands. Univ. Arizona Press, Tucson, Ariz.

Bahre, C.J. 1995. Human impacts on the grasslands of southeastern Arizona, p. 230-264. In: M.P. McClaran and T.R. Van Devender (eds.), The Desert Grassland. Univ. Arizona Press, Tucson, Ariz.

Bock, C.E. and. J.H. Bock. 1990. Effects of fire on wildlife in southwestern lowland habitats, p. 50-64. In: J.S. Krammes (tech. coord.), Effects of fire management of southwestern natural resources. USDA For. Serv. Gen. Tech. Rep. RM-1 91. Fort Collins, Colo.

Bock, C.E. and. J.H. Bock. 1992. Response of birds to wildfire in native vs. exotic Arizona grassland. Southwestern Nat. 37:73-81.

Bock, J.H., C.E. Bock, and J.R. McKnight. 1976. A study of the effects of grassland fires at The Research Ranch in southeastern Arizona. J. Ariz. Acad. Sci. 11:49-57.

Bock, C.E., J.H. Bock, W.R. Kennedy, and V.M. Hawthorne. 1984. Responses of birds, rodents, and vegetation to livestock exclosure in a semidesert grassland site. J. Range Manage. 37:239-242.

Cable, D.R. 1967. Fire effects on semi-desert grasses and shrubs. J. Range Manage. 20:170-176.

Cox, .R., F.A. Ibarra, and M.H. Martin. 1990. Fire effects on grasses in semiarid deserts, p. 43-49. In: J.S. Krammes (tech. coord.), Effects of fire management of southwestern natural resources USDA For. Serv. Gen. Tech. Rep. RM-191. Fort Collins, Colo.

Fleischner, T.L. 1994. Ecological costs of livestock grazing in western North America. Cons. Biol. 8:269-644.

Hastings, J.R. and R.M. Turner. 1965. The changing mile: an ecological study of vegetation change with time in the lower mile of an arid and semiard region. Univ. Arizona Press, Tucson, Ariz.

Humphrey, R.R. 1949. Fire as a means of controlling velvet mesquite, burroweed, and cholla on southeastern Arizona ranges. J. Range Manage. 2:175-182.

Johnson, H.B. and H.S. Mayeux. 1992. Viewpoint: A view on species additions and deletions and the balance of nature. J. Range Manage. 45:322-333.

Jones, S.L. and M.T. Green. 1998. Baird's Sparrow status assessment and conservation plan. US Dept. of Interior, Fish and Wildl. Serv. Admin. Rep., May, 1998, Denver, Colo.

Knopf, F.L. 1994. Avian assemblages on altered grasslands. Studies in Avian Biol. 9 15:232-246.

Latta, M.J., C.J. Beardmore, and T.E. Corman. 1999. Arizona Partners in Flight Bird Conservation Plan version 1.0. Nongame and endangered wildlife program Tech. Rep. Arizona Game and Fish Dept., Phoenix, Ariz. 
Mack, R.N and J.N. Thompson. 1982. Evolution in steppe with few large, hoofed mammals. Amer. Nat. 119:757-773.

McNaughton, S.J. 1993. Grasses and grazers, science and management. Ecol. Appl. 3:17-20.

McPherson, G.R. 1995. The role of fire in the desert grasslands, p. 130-151. In: M.P. McClaran and T.R. Van Devender (eds.), The Desert Grassland. Univ. Arizona Press, Tucson, Ariz.

Parmenter, R.R and T.R. Van Devender. 1995. Diversity, spatial variability, and functional roles of vertebrates in the desert grassland, p. 196-229. In: M.P. McClaran and T.R. Van Devender (eds.), The Desert Grassland. Univ. Arizona Press, Tucson, Ariz.
Phillips, A., J. Marshall, and G. Monson. 1964. The birds of Arizona. Univ. Arizona Press, Tucson, Ariz.

Rising, J.D. 1996. The sparrows of the United States and Canada. Academic Press, San Diego, Calif.

Ruth, J.M. 1999. Cassin's Sparrow status assessment. Biological Technical Publication BTP-R6002-1999. USFWS, Denver, Colo.

USBLM. 1995. Ecological site inventory for Empire Ranch, USBLM Tucson Field Office, Tucson, Ariz.

USBLM. 1997. Ecological site inventory for Empire Ranch. USBLM Tucson Field Office, Tucson, Ariz.

USDA-NRCS. 1982. Site guide for MLRA 411. USDA-NRCS Arizona field office, Phoenix, Ariz.
USDA-NRCS. 1988. Site guide for MLRA 413. USDA-NRCS Arizona field office, Phoenix, Ariz.

USFWS. 1995. Migratory non-game birds of management concern in the United States: The 1995 list. Office of migratory bird management, USFWS, Washington, DC.

Whitford, W.G., G.S. Forbes, and G.I. Kerley. 1995. Diversity, spatial variability, and functional roles of invertebrates in desert grassland ecosystems, p. 152-195. In: M.P. McClaran and T.R. Van Devender (eds.), The Desert Grassland. Univ. Arizona Press, Tucson, Ariz.

Wright, H.A. and A.W. Bailey. 1980. Fire ecology and prescribed burning in the Great Plains-a research review. USDA For. Serv. Gen. Tech. Rep. INT-77, Ogden, Utah.

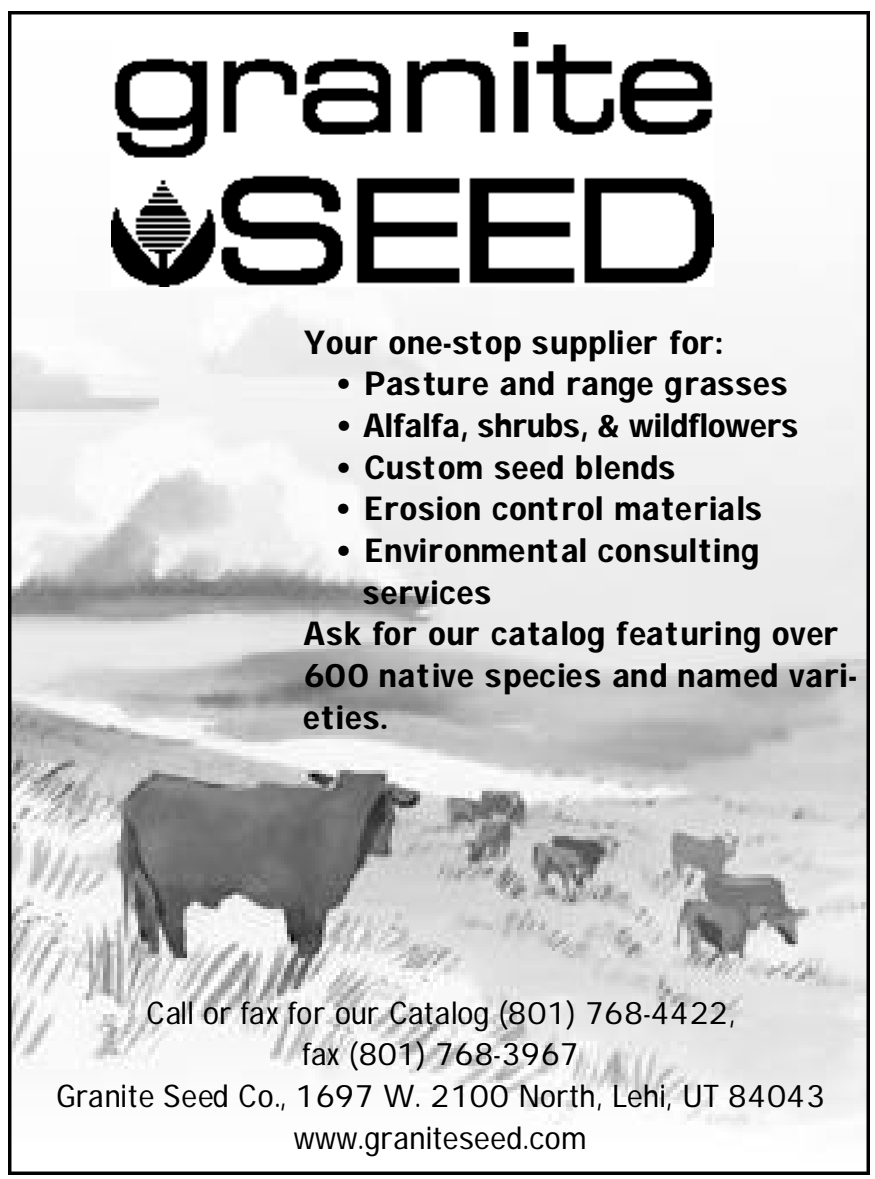

